\title{
Brevibacillus levickii sp. nov. and Aneurinibacillus terranovensis sp. nov., two novel thermoacidophiles isolated from geothermal soils of northern Victoria Land, Antarctica
}

Correspondence

N. A. Logan

N.A.Logan@gcal.ac.uk
R. N. Allan, ${ }^{1}$ L. Lebbe, ${ }^{2}$ J. Heyrman, ${ }^{2}$ P. De Vos, ${ }^{2}$ C. J. Buchanan ${ }^{1}$ and N. A. Logan ${ }^{1}$

\author{
${ }^{1}$ Department of Biological and Biomedical Sciences, Glasgow Caledonian University, \\ Cowcaddens Road, Glasgow G4 OBA, UK \\ ${ }^{2}$ Vakgroep BFM WE 10V Laboratorium voor Microbiologie, Universiteit Gent, K. L. \\ Ledeganckstraat 35, B-9000 Gent, Belgium
}

Thirteen strains of endospore-forming bacteria were isolated from geothermal soils at Cryptogam Ridge, the north-west slope of Mt Melbourne, and at the vents and summit of Mt Rittmann in northern Victoria Land, Antarctica. 16S rRNA gene sequencing, SDS-PAGE and routine phenotypic characterization tests indicated that the seven isolates from the north-west slope of Mt Melbourne represent a novel species of Brevibacillus and that the six isolates from Cryptogam Ridge and the vents and summit of Mt Rittmann represent a novel species of Aneurinibacillus. Brevibacillus strains were not isolated from the sites at Mt Rittmann or Cryptogam Ridge and Aneurinibacillus strains were not isolated from the north-west slope of Mt Melbourne. Preliminary metabolic studies revealed that L-glutamic acid, although not essential for growth, was utilized by both species. The Brevibacillus species possessed an uptake system specific for L-glutamic acid, whereas the Aneurinibacillus species possessed a more general uptake system capable of transporting other related amino acids. Both species utilized $\mathrm{a} \mathrm{K}^{+}$antiport system and similar energy systems for the uptake of L-glutamic acid. The rate of uptake by the Brevibacillus species type strain was 20 -fold greater than that shown by the Aneurinibacillus species type strain. The names Brevibacillus levickii sp. nov. and Aneurinibacillus terranovensis sp. nov. are proposed for the novel taxa; the type strains are Logan B-1657 $7^{\top}\left(=\right.$ LMG $22481^{\top}=$ CIP $\left.108307^{\top}\right)$ and Logan B-1599 $\left(\right.$ LMG $22483^{\top}=$ CIP $\left.108308^{\top}\right)$, respectively.

\section{INTRODUCTION}

Areas of geothermal activity in continental and maritime Antarctica are of particular biological interest because their moisture supplies are more regular than in other parts of the continent or in the circumpolar islands that are ice-free.

The GenBank/EMBL/DDBJ accession numbers for the 16S rRNA gene sequences of Brevibacillus levickii LMG 22481 ${ }^{\top}$, R-12317, R22009, LMG 22482, R-12318, R-22010 and R-22013 and Aneurinibacillus terranovensis LMG 22483' ${ }^{\top}$, R-12871, R-12872, R12873, R-12874 and LMG 22484 are AJ715378-AJ715390, respectively.

Graphs showing the effects of ionophores on glutamate uptake (Fig. A) and tables giving the fatty acid profiles (Table A) and the effects of various competitors (Table $\mathrm{B}$ ) and energy inhibitors (Table $\mathrm{C}$ ) on glutamate uptake in strains LMG 22481 ${ }^{\top}$ and LMG $22483^{\top}$ are available as supplementary material in IJSEM Online.
Vegetation at these sites is supported by the moisture created from the condensation of steam emissions of fumaroles and from the melting of ice (Broady, 1993). Two such sites are Mt Melbourne and Mt Rittmann in northern Victoria Land, Antarctica (Fig. 1a). Mt Melbourne (2733 m; $\left.74^{\circ} 21^{\prime} \mathrm{S}, 164^{\circ} 42^{\prime} \mathrm{E}\right)$ is a stratovolcano situated in the centre of a relatively young (probably $2-3 \times 10^{6}$ years B.P.) volcanic field that has been formed by a large number of small, individual eruptive centres (Broady et al., 1987) and some of the higher parts of the mountain bear large areas of hot ground and fumaroles. Located on the southern rim of the main summit crater of Mt Melbourne is a Specially Protected Area called Cryptogam Ridge (Fig. 1b). This is a deglaciated site with soil temperatures typically reaching $40-50{ }^{\circ} \mathrm{C}$ at depths of a few centimetres; it supports a unique community including algal and bryophyte species unknown elsewhere in Antarctica (Nicolaus et al., 1991). 

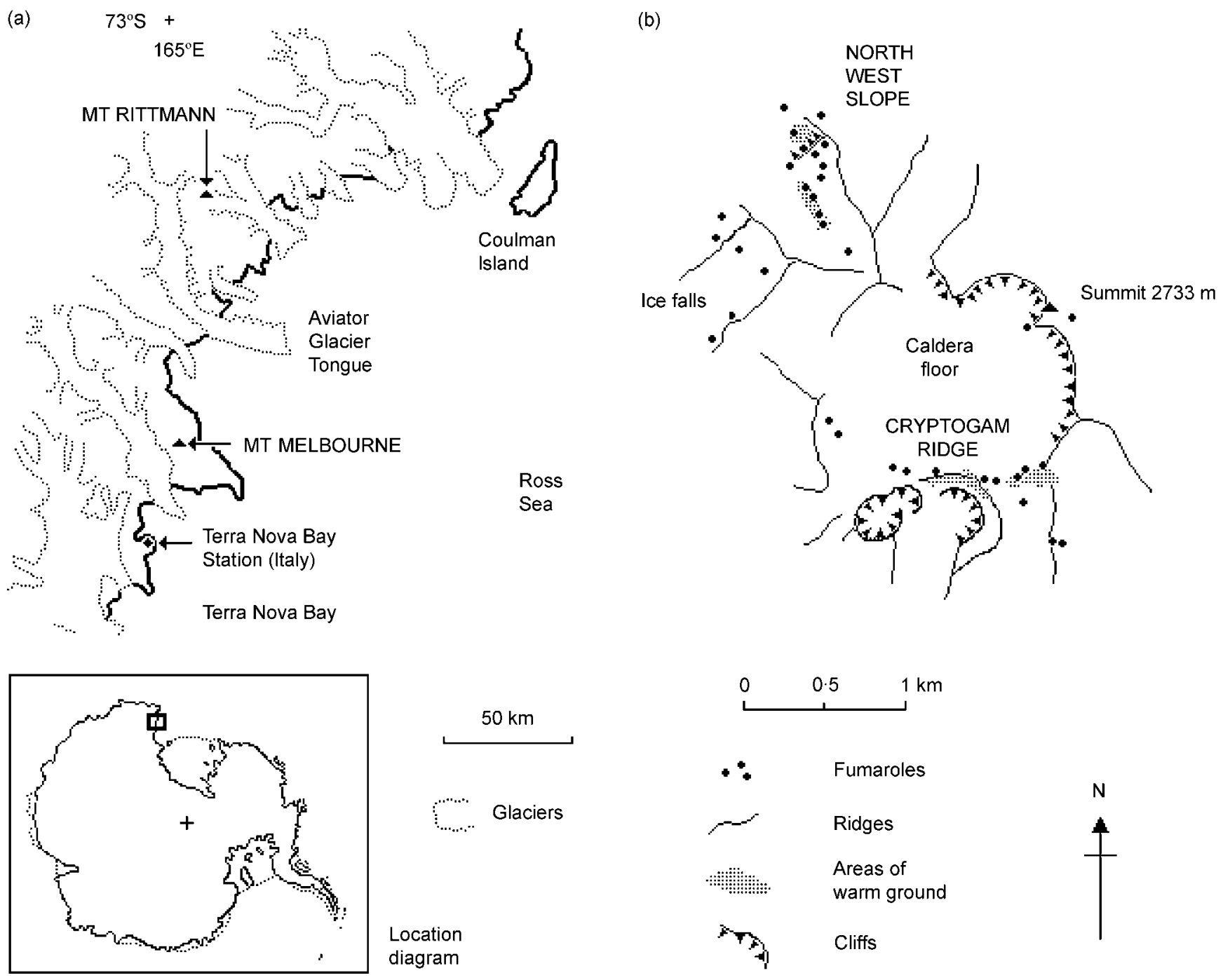

Fig. 1. (a) Map of northern Victoria Land showing the locations of Mt Melbourne and Mt Rittmann, with an inset map of Antarctica showing the location of the region (based on Logan et al., 2000). (b) Map of the caldera region at the summit region of Mt Melbourne and the location of Cryptogam Ridge (based on Broady et al., 1987).

The flora of the geothermally heated area of the north-west slope of the mountain is less well developed than that of Cryptogam Ridge. Mt Rittmann (2600 m; 73 27' S, $165^{\circ} 30^{\prime}$ E), which was discovered during the 4th Italian Expedition (1988-1989; Armienti \& Tripodo, 1991), is located in the Mountaineer Range, about $110 \mathrm{~km}$ north of Mt Melbourne. During the 6th Italian Antarctic Expedition (1990-1991), fumaroles and heated ground were discovered in a minor caldera rim of this mountain (Bonaccorso et al., 1991). The soil surface temperature is $34 \cdot 4-41 \cdot 5^{\circ} \mathrm{C}$ and there is patchy development of vegetation. Although the soils of the two mountains are comparable, Bargagli et al. (1996) showed that there were differences in the mineral contents of soil samples collected from Mt Melbourne (higher $\mathrm{Cu}$ and $\mathrm{Zn}$ ) and Mt Rittmann (higher $\mathrm{Cd}$ and $\mathrm{Pb}$ ). During the 11th and 14th Italian Antarctic Expeditions (1995-1996 and 19981999, respectively) samples of heated soils were collected from Cryptogam Ridge, the north-west slope of $\mathrm{Mt}$ Melbourne and Mt Rittmann, in order to study the aerobic endospore-forming bacterial floras of these sites (Logan et al., 2000). This report describes the characterization of six strains of a novel Aneurinibacillus species isolated from soils of Cryptogam Ridge and Mt Rittmann and seven strains of a novel Brevibacillus species from the northwest slope of Mt Melbourne. The names Aneurinibacillus terranovensis sp. nov. and Brevibacillus levickii sp. nov. are proposed for these novel taxa.

Brevibacillus and Aneurinibacillus were established as new genera arising from the reclassification of the Bacillus brevis and Bacillus aneurinilyticus groups of species (Shida et al., 1996). Currently, there are 12 Brevibacillus species and four Aneurinibacillus species. Given their poor reactivity in conventional identification tests, it has been difficult to 
distinguish between species of these genera (Logan et al., 2002); amplified rDNA restriction analysis is also unable to discriminate between all of the species (Logan et al., 2002). However, some techniques have proved successful, e.g. SDS-PAGE (Logan et al., 2002) and, more recently, sequencing of the hypervariable regions that are conserved within species and diverge between species (Goto et al., 2004). The unique environmental conditions from which these species have been isolated, the restriction of the Brevibacillus strains to the north-west slope of Mt Melbourne and the absence of Aneurinibacillus strains from that site stimulated us to compare their metabolism. The investigation of the metabolic pathways of these organisms could be of value in the characterization of these two species, given their poor reactivities in conventional identification tests. Glutamate uptake and metabolism were studied, given the probable availability of this substrate in these habitats from primary producers such as cyanobacteria and microalgae. This is not only the first metabolic study of this kind for members of these genera, but also for aerobic endospore-forming bacteria from Antarctic geothermal environments.

\section{METHODS}

Isolation of strains. Strain isolation details are given by Logan et al. (2000). Strains LMG 22482, R-22010, R-12318, R-22009, R-12317, LMG 22481 ${ }^{\mathrm{T}}$ and R-22013 (strains Logan B-1598, B-1606, $\mathrm{B}-1607, \mathrm{~B}-1608, \mathrm{~B}-1611, \mathrm{~B}-1657^{\mathrm{T}}$ and $\mathrm{B}-1659$, respectively) were isolated from the north-west slope of Mt Melbourne. Strains LMG $22483^{\mathrm{T}}$ and R-12871 (strains Logan $\mathrm{B}-1599^{\mathrm{T}}$ and $\mathrm{B}-1624$, respectively) were isolated from Cryptogam Ridge at Mt Melbourne. Strains R-12872 and R-12873 (strains Logan B-1633 and B-1634, respectively) were isolated from vents of Mt Rittmann and strains R-12874 and LMG 22484 (strains Logan B-1636 and B-1641, respectively) were isolated from the summit of Mt Rittmann.

Cultivation and maintenance of strains. Strains were initially grown on a variety of media in order to identify which medium supported optimal growth. Media tested included full-strength, half-strength (1/2 BFA) and a quarter-strength version (1/4 BFA) of Bacillus fumarioli agar (BFA; Logan et al., 2000). BFA contained

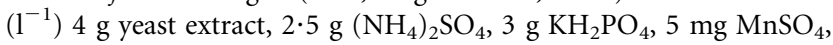
$0 \cdot 2 \mathrm{~g} \mathrm{MgSO}_{4} \cdot 7 \mathrm{H}_{2} \mathrm{O}, 0 \cdot 25 \mathrm{~g} \mathrm{CaCl}_{2} .2 \mathrm{H}_{2} \mathrm{O}$ and $18 \mathrm{~g}$ agar, adjusted to $\mathrm{pH} 5 \cdot 5$. A defined medium was created, based on BFA and 1/2 BFA, in which the yeast extract and $\left(\mathrm{NH}_{4}\right)_{2} \mathrm{SO}_{4}$ were omitted and replaced with $1 \mathrm{ml}$ vitamin solution described by Dijkhuizen et al. (1988) and $0.06 \mathrm{~g}$ each of $13 \mathrm{~L}$ - and DL-amino acids (L-alanine, L-asparagine, L-aspartic acid, L-cysteine, L-glutamic acid, L-isoleucine, L-leucine, L-lysine, L-methionine, DL-norleucine, DL-norvaline, L-threonine and L-valine). The amino acids to be included in this defined medium were determined by creating a broth consisting of all 23 amino acids and then creating subsequent broths in which families of these amino acids or single amino acids were omitted. Those amino acids that were omitted from broths that yielded no growth were deemed as being essential for growth and included in the defined medium. This defined medium was also prepared without the vitamin solution. A variation of Davis and Mingioli minimal medium (Cruickshank et al., 1975) was also used; it contained $\left(1^{-1}\right)$ $20 \mathrm{ml}$ sterile $10 \%$ glucose solution, $3.5 \mathrm{~g} \mathrm{~K}_{2} \mathrm{HPO}_{4}, 1.5 \mathrm{~g} \mathrm{KH}_{2} \mathrm{PO}_{4}$, $0.5 \mathrm{~g}$ sodium citrate $\left(\mathrm{Na}_{3} \mathrm{C}_{6} \mathrm{H}_{5} \mathrm{O}_{7} \cdot 2 \mathrm{H}_{2} \mathrm{O}\right), 0 \cdot 1 \mathrm{~g} \mathrm{MgSO} .7 \mathrm{H}_{2} \mathrm{O}, 1 \mathrm{~g}$ $\left(\mathrm{NH}_{4}\right)_{2} \mathrm{SO}_{4}, 20 \mathrm{~g}$ agar and $2 \mathrm{~g}$ yeast extract. A further variation of this medium lacked both glucose and $\left(\mathrm{NH}_{4}\right)_{2} \mathrm{SO}_{4}$. The most rapid and profuse growth was achieved through the use of $1 / 2$ BFA at $\mathrm{pH} 5.5$ and $40^{\circ} \mathrm{C}$; this medium was used throughout the remainder of the study along with the broth version, 1/2 BFB (Bacillus fumarioli broth), which lacked agar and $\mathrm{MnSO}_{4}$. A broth version of the defined medium, lacking agar and $\mathrm{MnSO}_{4}$, was used for the metabolic studies.

DNA preparation, DNA base composition and 16S rRNA gene sequencing. These were carried out as described by Logan et al. (2000).

SDS-PAGE of whole-cell proteins. Cells were obtained after $48 \mathrm{~h}$ growth on $1 / 2 \mathrm{BFA}$ at $28^{\circ} \mathrm{C}$. The SDS protein extracts were prepared and electrophoresed according to Pot et al. (1994) and data were collected and interpreted as described by Vauterin \& Vauterin (1992).

DNA-DNA relatedness. DNA-DNA hybridization was performed using a modification of the microplate method of Ezaki et al. (1989), as described by Willems et al. (2001).

GC analysis of methylated fatty acids. Cells were grown for $48 \mathrm{~h}$ on $1 / 2 \mathrm{BFA}$ at $28^{\circ} \mathrm{C}$ and subsequently analysed as described by Logan et al. (2000).

Phenotypic analysis. Isolates were grown on $1 / 2 \mathrm{BFA}$ at $\mathrm{pH} 5 \cdot 5$ and $40{ }^{\circ} \mathrm{C}$ for $24-72 \mathrm{~h}$ and vegetative cells and sporangial morphologies were observed as described by Logan et al. (2000). As colonies of some strains on agar media were tenacious and cohesive, capsule production was investigated using an adaptation of the India ink wet-film method described by Duguid (1951); initially the cells were stained with $1 \%$ rose Bengal and India ink was substituted with $1 \%$ nigrosin. Temperature ranges for growth were determined by incubating the organisms in $10 \mathrm{ml} 1 / 2 \mathrm{BFB}$ in water baths set at 15, 20, $25,30,37,40,45,50$ and $55^{\circ} \mathrm{C}$. The $\mathrm{pH}$ ranges for growth were determined by growing the organisms at $40^{\circ} \mathrm{C}$ in $10 \mathrm{ml} 1 / 2 \mathrm{BFB}$ adjusted to $\mathrm{pH} 3 \cdot 5,4 \cdot 0,4 \cdot 5,5 \cdot 0,5 \cdot 5,6 \cdot 0,6 \cdot 5$ and $7 \cdot 0$ using $\mathrm{HCl}$ and $\mathrm{NaOH}$. Turbidities of both series were determined using a spectrophotometer (Cecil CE1010) set at $680 \mathrm{~nm}$, at $24 \mathrm{~h}$ intervals. The isolates were tested for anaerobic and microaerobic growth in GasPak jars (BBL) using aerobically grown isolates as controls; a Campylobacter sachet (BBL) was used to create microaerobic conditions. Haemolysis was tested using $5 \%$ horse blood with Columbia Blood Agar base (Oxoid) and 1/2 BFA as a base. Egg-yolk reaction, starch hydrolysis and casein hydrolysis were tested using the methods of Gordon et al. (1973) with 1/2 BFA as the base. Gelatin hydrolysis was determined by aseptically removing the charcoal gelatin from API 20E strips (bioMérieux) and adding them to $1 \mathrm{ml}$ $1 / 2$ BFB before inoculation. Strains were also characterized using the API 20E kit as described by Logan \& Berkeley (1984). All isolates were tested for carbon source utilization and for acid or alkali production from the same substrates using the Biotype 100 gallery (bioMérieux), which comprises 99 carbon sources, such as carbohydrates, amino acids and organic acids, and one control tube. 1/2 BFB $(200 \mathrm{ml})$ was inoculated and incubated for $24 \mathrm{~h}$ at $40{ }^{\circ} \mathrm{C}$. The cells were then centrifuged at $2000 \mathrm{~g}$ for $15 \mathrm{~min}$, the supernatant was discarded, the pellet was resuspended in $10 \mathrm{ml}$ of $10 \mathrm{mM}$ phosphate buffer and recentrifuged (2000 $g$ for $15 \mathrm{~min}$ ). The resulting supernatant was discarded and the pellet was resuspended in $2 \mathrm{ml}$ phosphate buffer. Drops of this bacterial suspension were added to sterile $0 \cdot 45 \%$ sodium chloride solution until a turbidity equivalent to 3 on the McFarland scale was achieved. For carbon source utilization testing, this suspension $(2 \mathrm{ml})$ was homogenized in $60 \mathrm{ml}$ Biotype medium 2 (bioMérieux) and for acid or alkaline reactions, $2 \mathrm{ml}$ suspension was homogenized in $60 \mathrm{ml} 1 / 2 \mathrm{BFB}$ prepared without yeast extract or $\left(\mathrm{NH}_{4}\right)_{2} \mathrm{SO}_{4}$, but containing phenol red at a final concentration of $0.006 \%$. In order to allow reading of acid and alkaline reactions, and direct comparison with other Aneurinibacillus 


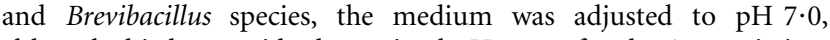
although this lay outside the optimal $\mathrm{pH}$ range for the Antarctic isolates. These suspensions were used to inoculate both the tubes and cupules of the Biotype 100 strips. For utilization tests, results were read at $24 \mathrm{~h}$ intervals according to the manufacturer's instructions; for most substrates, utilization was indicated by turbidity. For acid or alkali production, results were read at $24 \mathrm{~h}$ intervals for $96 \mathrm{~h}$ with a yellow colour reaction scored as positive for acid reactions and a violet colour scored as positive for alkaline reactions. It was noted, however, that several tubes showed reactions immediately upon inoculation - two tubes produced alkaline reactions and several other tubes, mostly containing organic acids, gave acid reactions; these were not regarded as evidence of substrate utilization.

Metabolic studies. A standard glutamate transport assay was performed on strains LMG $22483^{\mathrm{T}}$ and LMG $22481^{\mathrm{T}}$ to determine the uptake of glutamate under normal conditions. 1/2 BFB $(200 \mathrm{ml})$ was inoculated and incubated for $24 \mathrm{~h}$ at $40{ }^{\circ} \mathrm{C}$ in an orbital incubator. Cells were then centrifuged at $2000 \mathrm{~g}$ for $15 \mathrm{~min}$, the supernatant was discarded, and the pellet was resuspended in $10 \mathrm{ml}$ of $10 \mathrm{mM}$ phosphate buffer $\left(\mathrm{KH}_{2} \mathrm{PO}_{4} / \mathrm{K}_{2} \mathrm{HPO}_{4}, \mathrm{pH} 7\right)$ and recentrifuged (2000 $g$ for $15 \mathrm{~min}$ ). The resulting supernatant was discarded and the pellet was resuspended in $2 \mathrm{ml}$ phosphate buffer. Defined medium $(200 \mathrm{ml})$ was inoculated with this suspension $(0 \cdot 3 \mathrm{ml})$ and incubated at $40{ }^{\circ} \mathrm{C}$ for $17 \mathrm{~h}$. Cells were harvested as before and resuspended in $2 \mathrm{ml}$ phosphate buffer. Aliquots $(800 \mu \mathrm{l})$ of the cell suspension were incubated with $195 \mu$ phosphate buffer for $5 \mathrm{~min}$ at $40{ }^{\circ} \mathrm{C}$ and $5 \mu \mathrm{l}$ of $0.05 \mu \mathrm{Ci}(1.85 \mathrm{kBq})\left[{ }^{14} \mathrm{C}\right] \mathrm{L}$-glutamic acid $(10 \mathrm{mM})$ was introduced to initiate transport measurement. Samples $(150 \mu \mathrm{l})$ were taken from the $1 \mathrm{ml}$ assay mixture at $30 \mathrm{~s}$ intervals for $150 \mathrm{~s}$ and cells were immediately filtered on glass microfibre GF/B discs (Whatman) and washed in $2 \times 10 \mathrm{ml}$ cold phosphate buffer. The filters were then dried and the ${ }^{14} \mathrm{C}$ in the samples was assayed by liquid scintillation counting using $4 \mathrm{ml}$ scintillation fluid (Optiscint HiSafe; Perkin Elmer).

Competition experiments were carried out using unlabelled amino acids (L-glutamic acid, D-glutamic acid, L-proline, L-arginine and DLornithine) to determine whether the uptake system used by the strains was specific for L-glutamate or was also involved in the uptake of other, metabolically related amino acids. To create a 50 -fold molar excess of each amino acid, in comparison to $\left[{ }^{14} \mathrm{C}\right] \mathrm{L}$-glutamic acid, $100 \mu \mathrm{l}$ of each amino acid $(25 \mathrm{mM})$ with $95 \mu$ phosphate buffer was introduced to the cell suspension and incubated for 5 min before adding $\left[{ }^{14} \mathrm{C}\right] \mathrm{L}$ glutamic acid. Secondary competition experiments involved testing the uptake of $\left[{ }^{14} \mathrm{C}\right]$ arginine and $\left[{ }^{14} \mathrm{C}\right]$ proline $(0 \cdot 05 \mu \mathrm{Ci})$ in the presence of a 50-fold molar excess of unlabelled L-glutamic acid. The same volumes of amino acids, radiolabelled substrate and phosphate buffer were used as before and the cells were pre-grown in the presence of L-glutamic acid (to induce uptake).

To determine whether $\mathrm{Na}^{+}$or $\mathrm{K}^{+}$channels were involved in glutamate uptake, $1 \mathrm{ml}$ assay mixtures were prepared with valinomycin $\left(\mathrm{K}^{+}\right.$ ionophore), monensin $\left(\mathrm{Na}^{+}\right.$ionophore) or nigericin $\left(\mathrm{K}^{+} / \mathrm{Na}^{+}\right.$ ionophore) (final concentrations of $10,0 \cdot 1$ and $10 \mu \mathrm{M}$, respectively). The ionophores, $10 \mu \mathrm{l}$ of $1 \mathrm{mM}$ valinomycin (dissolved in DMSO), $10 \mu \mathrm{l}$ of $10 \mu \mathrm{M}$ monensin (dissolved in DMSO) or $10 \mu \mathrm{l}$ of $1 \mathrm{mM}$ nigericin (dissolved in ethanol), respectively, were introduced and incubated for $5 \mathrm{~min}$ before the addition of $\left[{ }^{14} \mathrm{C}\right] \mathrm{L}$-glutamic acid. Controls containing only $10 \mu \mathrm{DMSO}$ or $10 \mu \mathrm{l}$ ethanol were used to ensure that the ionophores were the only differing factors in the experiments.

To create artificial $\mathrm{Na}^{+}, \mathrm{K}^{+}$and $\mathrm{H}^{+}$ion gradients, $\mathrm{NaCl}, \mathrm{KCl}$ or $\mathrm{HCl}$, respectively, were introduced to create final concentrations of 50 or $100 \mathrm{mM}$ in the $1 \mathrm{ml}$ assay mixtures, $5 \mathrm{~min}$ prior to the addition of $\left[{ }^{14} \mathrm{C}\right] \mathrm{L}$-glutamic acid. To determine whether glutamate uptake is linked to an osmotic effect, sucrose was introduced to create final concentrations of 50 and $100 \mathrm{mM}$ in the $1 \mathrm{ml}$ working suspensions; the resulting mixtures were incubated for $5 \mathrm{~min}$ before adding $\left[{ }^{14} \mathrm{C}\right] \mathrm{L}$-glutamic acid.

Energy inhibitors were employed to identify the system used by the micro-organisms for glutamate uptake. Sodium fluoride (glycolysis inhibitor), dinitrophenol (respiration uncoupler) or sodium arsenate (ATP synthesis inhibitor) were introduced to the $1 \mathrm{ml}$ working stock to give $10 \mathrm{mM}$ final concentrations and incubated for 5 min before adding $\left[{ }^{14} \mathrm{C}\right] \mathrm{L}$-glutamic acid. Iodoacetic acid (glycolysis inhibitor) or $N$-ethylmaleimide $p$-chloromercuribenzoate ( $\mathrm{S}$-H reagent, in ethanol) were introduced to the cell suspension to give $5 \mathrm{mM}$ final concentrations and incubated for $5 \mathrm{~min}$ before adding $\left[{ }^{14} \mathrm{C}\right] \mathrm{L}$-glutamic acid. Carbonyl cyanide $m$-chlorophenyl hydrazone [respiration uncoupler (collapses ion gradients), in ethanol] or $\mathrm{N}$ - $\mathrm{N}$-dicyclohexylcarbodiimide (ATPase inhibitor, in ethanol) were introduced to the cell suspension to give $0 \cdot 1 \mathrm{mM}$ final concentrations and incubated for 5 min before adding $\left[{ }^{14} \mathrm{C}\right] \mathrm{L}$-glutamic acid. An ethanol control was used to ensure that the energy inhibitors were the only differing factors in the experiment.

\section{RESULTS AND DISCUSSION}

\section{Cultivation of strains}

All of the Antarctic isolates demonstrated poor outgrowth on $1 / 2 \mathrm{BFA}$ at $\mathrm{pH} 5.5$ at $40^{\circ} \mathrm{C}$, but restreaking the few initial colonies on the same plate and reincubating resulted in better growth. On BFA with and without $\left(\mathrm{NH}_{4}\right)_{2} \mathrm{SO}_{4}$, the seven isolates from the north-west slope of Mt Melbourne demonstrated growth equivalent to that on $1 / 2 \mathrm{BFA}$, whereas the other six isolates generated less growth. This suggested that the Cryptogam Ridge and Mt Rittmann isolates, in comparison with the Mt Melbourne northwest slope isolates, have a preference for nutritionally weaker media. This inference was supported by the observation that only north-west slope isolates grew on egg-yolk agar and blood agar (both prepared with a blood agar base), and on both variants of Davis and Mingioli minimal medium, all of which are comparatively rich media in comparison with $1 / 2 \mathrm{BFA}$. It is also consistent with the observation that the non-slope isolates, in comparison with the north-west slope isolates, grew better in the nutritionally weaker unsolidified defined medium. All of the isolates demonstrated less growth on $1 / 4 \mathrm{BFA}$. The best growth was achieved using liquid rather than solid media, especially $1 / 2$ BFB and unsolidified defined medium, which is consistent with a preference for microaerobic conditions.

\section{$16 S$ rRNA gene sequencing}

The nearly complete 16S rRNA gene sequences of all 13 strains were analysed. Clustering of the obtained sequences revealed two groups (Fig. 2): one containing strains isolated from the north-west slope of Mt Melbourne and one containing strains isolated from Cryptogam Ridge at $\mathrm{Mt}$ Melbourne, as well as the Mt Rittmann isolates. Both groups show high internal similarity (pairwise similarities of 99.7-99.9 and 99.9-100.0\%, respectively). According to a FASTA search (Pearson \& Lipman, 1988), strains 


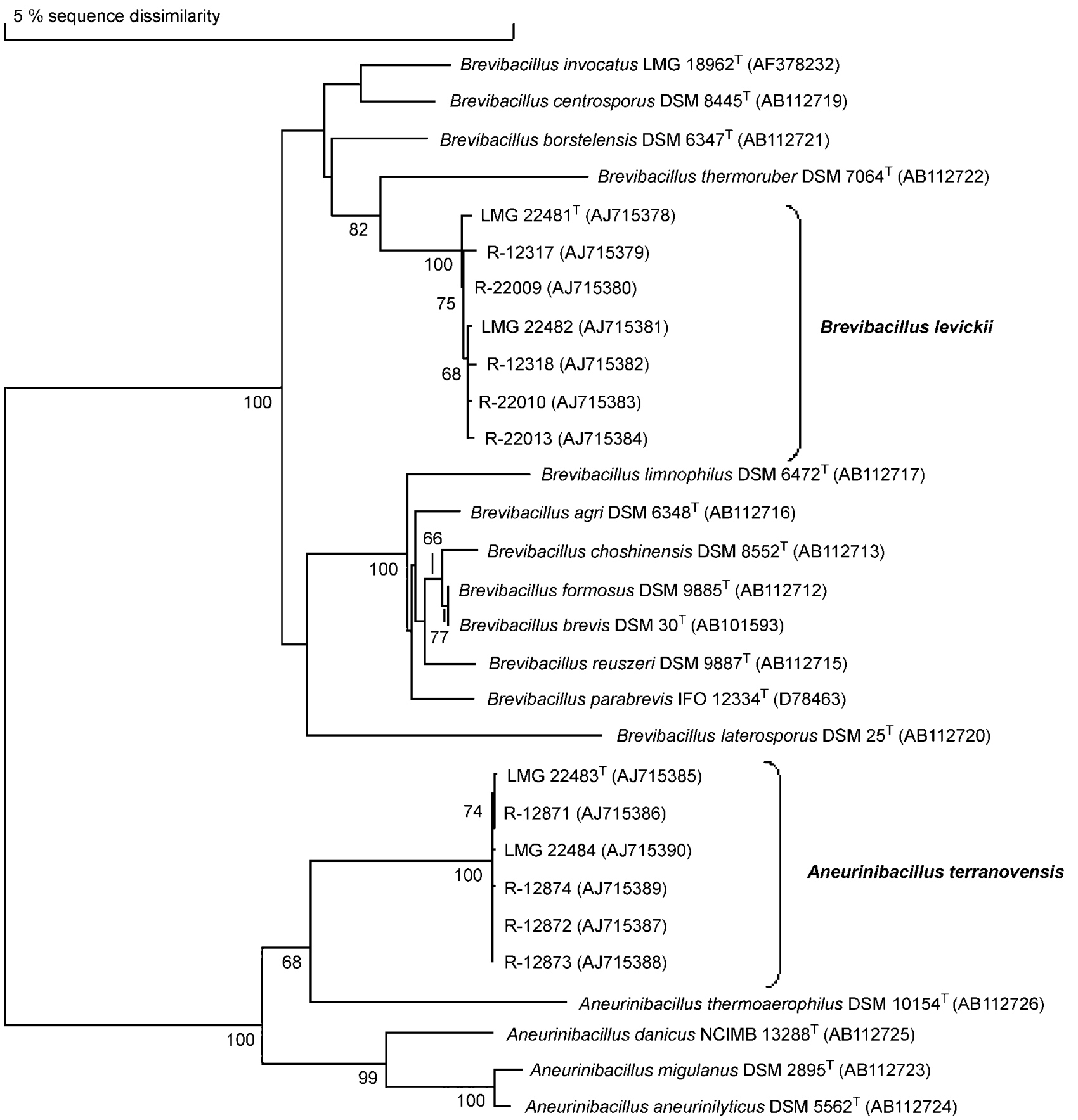

Fig. 2. Phylogenetic positions based on neighbour-joining of the $16 \mathrm{~S}$ rRNA gene sequences of the Antarctic isolates among the type strains of Brevibacillus and Aneurinibacillus. Bootstrap values (expressed as percentages of 1000 replications) greater than $60 \%$ are shown at branch points.

belonging to the first group show highest sequence similarity to the Brevibacillus borstelensis type strain $(97 \cdot 0$ $97 \cdot 2 \%$ similarity), but are distinct from it in SDS-PAGE analysis (see below). The sequence similarity to all other Brevibacillus species is well below $97 \cdot 0 \%$. These low sequence similarities, on the borderline of species delineation (Stackebrandt \& Goebel, 1994; Stackebrandt et al.,
2002), together with the specific growth conditions of the strains suggest that the strains possibly represent a novel Brevibacillus species. DNA-DNA relatedness measurements confirmed this suggestion, with Antarctic strain LMG $22841^{\mathrm{T}}$ and Brevibacillus borstelensis $\mathrm{LMG} 16009^{\mathrm{T}}$ showing reciprocal DNA-DNA association values of 18.3 and $18.9 \%$. These strains are subsequently referred to as Brevibacillus 


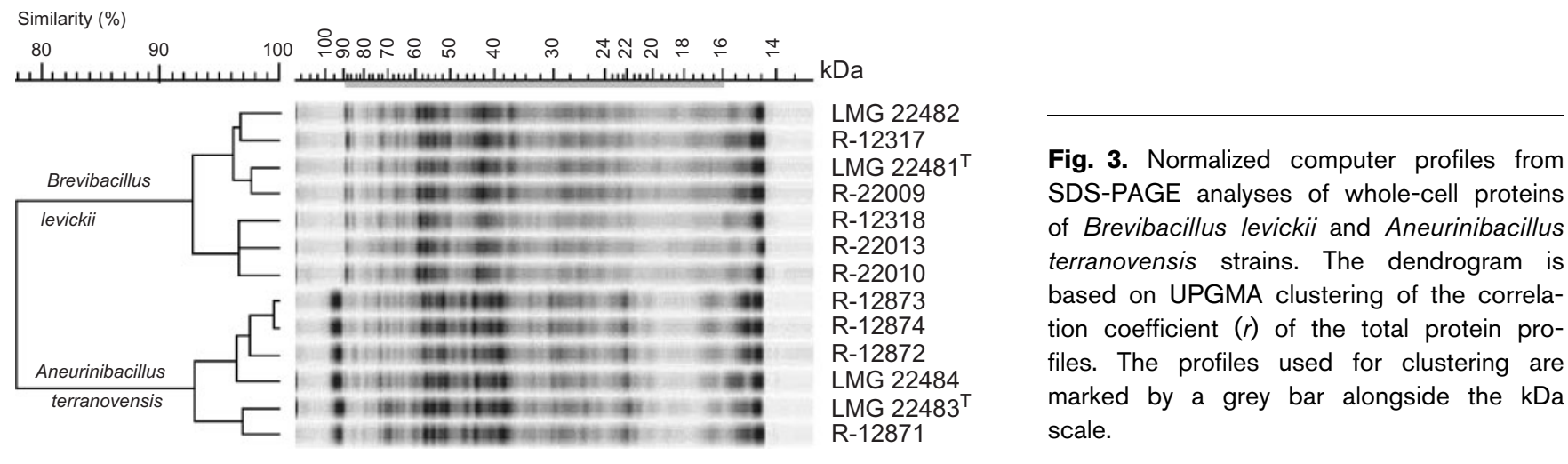

levickii sp. nov. (Fig. 2). Based on 16S rRNA gene sequences, the second group of strains is most closely related to members of the genus Aneurinibacillus (sequence similarities of 95-96\% according to a FASTA search) and forms a tight cluster with them (Fig. 2). According to these sequence similarities $(<97 \%)$, the strains can be attributed to a novel Aneurinibacillus genospecies (Stackebrandt et al., 2002); these strains are subsequently referred to as Aneurinibacillus terranovensis sp. nov. (Fig. 2).

\section{SDS-PAGE}

Numerical analysis of SDS-PAGE patterns of whole-cell proteins (Fig. 3) also enabled discrimination of the 13 isolates in the two groups revealed by $16 \mathrm{~S}$ rRNA gene sequence analysis. The Brevibacillus levickii strains grouped at $93-98 \%$ similarity and the patterns represent members of a distinct and homogeneous taxon. Furthermore, the SDS-PAGE profile of Brevibacillus levickii was clearly different from that of the type strain of Brevibacillus borstelensis (below $65 \%$ similarity; data not shown), the species with which the strains share 97.0-97.2\% $16 \mathrm{~S}$ rRNA gene sequence similarity. The A. terranovensis strains grouped at $93-99 \%$ similarity and the patterns represent members of a distinct and homogeneous taxon. The two clusters merged at a low and insignificant similarity, indicating that the taxa are not closely related.

\section{Fatty acid analysis}

The existing Brevibacillus species show a dominance of the fatty acids anteiso- $\mathrm{C}_{15: 0}$ and iso- $\mathrm{C}_{15: 0}$, whereas the existing species of Aneurinibacillus have iso- $\mathrm{C}_{15: 0}$ as the dominant fatty acid (other fatty acids account for less than $20 \%$ of the total; Supplementary Table A in IJSEM Online). The fatty acid profiles of the Antarctic strains are difficult to compare with those of the other species since the strains failed to grow under standard conditions (trypticase soy agar, $24 \mathrm{~h}, 28^{\circ} \mathrm{C}$ ). Instead, the fatty acid profile of the Antarctic strains was determined after $48 \mathrm{~h}$ growth on $1 / 2$ BFA medium at $28^{\circ} \mathrm{C}$. It has been reported that the fatty acid content, especially branched-chain fatty acids, can be greatly affected by the cultivation medium (Suzuki et al., 1993) and thus the medium could be responsible for the observed differences. The resulting profiles of the Brevibacillus levickii strains showed high amounts of anteiso$\mathrm{C}_{15: 0}$ (mean of $74.5 \%$ ), whereas A. terranovensis has high amounts of iso- $\mathrm{C}_{15: 0}$ and anteiso- $\mathrm{C}_{15: 0}$ (Supplementary Table A).
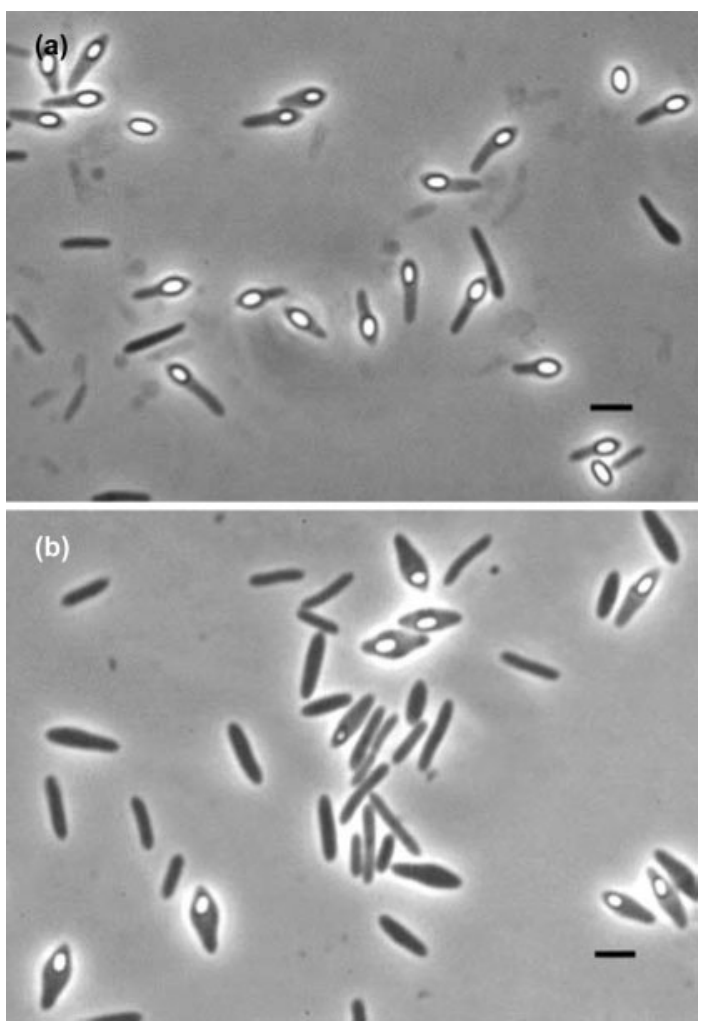

Fig. 4. (a) Photomicrograph of sporangia and vegetative cells of Brevibacillus levickii strain R-12317 viewed by phasecontrast microscopy; ellipsoidal spores lie subterminally and terminally in swollen sporangia. Bar, $2 \mu \mathrm{m}$. (b) Photomicrograph of sporangia and vegetative cells of Aneurinibacillus terranovensis strain R-12871 viewed by phase-contrast microscopy; ellipsoidal spores lie centrally, paracentrally and subterminally in swollen sporangia. Bar, $2 \mu \mathrm{m}$. 


\section{Phenotypic characterization}

The strains were Gram-positive motile rods that lost the positive reaction of the Gram stain in 24-48 $\mathrm{h}$ and formed ellipsoidal spores in swollen sporangia (Fig. 4a, b). On 1/2 BFA plates, the Brevibacillus strains formed tough, adherent colonies, whereas colonies of the Aneurinibacillus strains were butyrous. The A. terranovensis and Brevibacillus levickii strains showed many phenotypic similarities and few biochemical characters useful for differentiation. Their reactions in the various tests are summarized in the species descriptions below and in Table 1 and Table 2. Sporangial morphologies were notably different between the species: sporangia of $A$. terranovensis were greatly swollen by central to subterminal spores, whereas those of Brevibacillus levickii were less swollen with subterminal and terminal spores (Fig. 4a, b). Strains of both species appeared pleomorphic and filamentous when grown in $1 / 2 \mathrm{BFB}$, whereas cultivation in defined medium generated cells of regular appearance. All strains were weakly positive for catalase and grew well in aerobic conditions but, as explained above, outgrowth was poor so restreaking on the same plate was necessary in order to obtain satisfactory growth; such outgrowth problems were not seen with plates incubated in microaerobic conditions. This is consistent with the observation that growth in broth media was always more abundant than growth on their solid counterparts. Although agar colonies of Brevibacillus were adherent and difficult to emulsify in liquid media, capsule production could not be demonstrated. Strains of both species showed negative or weak reactions in many of the phenotypic tests; for example, no hydrolysis was observed around colonies on starch agar and weak reactions only became apparent after the colonies had been scraped from the surface of the medium. In the

Table 1. Phenotypic characters that can be used to differentiate Brevibacillus levickii from other Brevibacillus species

Species: 1, Brevibacillus levickii (7 strains); 2, B. agri; 3, B. borstelensis; 4, B. brevis; 5, B. centrosporus; 6, B. choshinensis; 7, B. formosus; 8, B. invocatus; 9, B. laterosporus; 10, B. parabrevis; 11, B. reuszeri. +, >85\% positive; (+), 75-84\% positive; v, variable (16-74\% positive); -, $0-15 \%$ positive; $w$, weak positive reaction; NA, no data available.

\begin{tabular}{|c|c|c|c|c|c|c|c|c|c|c|c|}
\hline Character & $1^{\star}$ & 2 & 3 & 4 & 5 & 6 & 7 & 8 & 9 & 10 & 11 \\
\hline \multicolumn{12}{|l|}{ Growth temperature $\left({ }^{\circ} \mathrm{C}\right)$} \\
\hline Range & $15-55$ & $20-50$ & $20-50$ & $20-45$ & $10-40$ & NA & $20-45$ & $15-35$ & $15-50$ & $20-45$ & $20-45$ \\
\hline $\mathrm{pH}$ range & $4 \cdot 5-6 \cdot 5$ & $6-9$ & NA & $6-9$ & NA & NA & $6-9$ & $6 \cdot 0-8 \cdot 5$ & $\mathrm{NA}$ & $6-9$ & $6-9$ \\
\hline Optimum pH & $5 \cdot 0-5 \cdot 5$ & $7 \cdot 0-7 \cdot 5$ & NA & $7 \cdot 0-7 \cdot 5$ & NA & NA & $7 \cdot 0-7 \cdot 5$ & NA & $\mathrm{NA}$ & $7 \cdot 0-7 \cdot 5$ & $6 \cdot 5-7 \cdot 0$ \\
\hline \multicolumn{12}{|l|}{ Hydrolysis of: } \\
\hline Casein & $\mathrm{v} / \mathrm{w}$ & + & + & + & - & - & + & - & + & + & - \\
\hline Gelatin & + & + & + & + & - & - & + & - & + & + & + \\
\hline Starch & $\mathrm{w}$ & $\mathrm{w}$ & - & + & - & - & - & - & - & - & + \\
\hline \multicolumn{12}{|l|}{ Assimilation of: } \\
\hline Glutamate & + & + & + & + & $\mathrm{v}$ & - & + & - & $\mathrm{v}$ & + & + \\
\hline DL-Glycerate & + & - & + & - & - & - & - & - & + & - & + \\
\hline Glycerol & $(+)$ & + & - & + & - & - & + & - & + & + & - \\
\hline DL-Lactate & + & + & - & - & + & - & + & - & - & - & + \\
\hline Lactulose & - & - & - & - & - & - & - & - & - & - & + \\
\hline Maltose & $(+)$ & + & - & + & - & - & + & - & + & + & - \\
\hline D-Mannitol & $(+)$ & + & - & + & + & $\mathrm{v}$ & + & - & + & + & + \\
\hline$N$-Acetyl-D-glucosamine & + & + & + & + & + & $\mathrm{v}$ & + & - & + & + & + \\
\hline Phenylacetate & - & + & - & + & + & $\mathrm{v}$ & + & + & - & + & + \\
\hline Quinate & $(+)$ & - & - & - & - & - & - & + & - & - & - \\
\hline Sucrose & + & + & - & + & - & - & + & - & - & + & - \\
\hline
\end{tabular}

${ }^{\star} B$. levickii strains were characterized at $\mathrm{pH} 5 \cdot 5$; other species were tested at $\mathrm{pH} 6 \cdot 5-7 \cdot 0$.

$\dagger$ Type strain gives a positive reaction. 
Table 2. Phenotypic characters that can be used to differentiate Aneurinibacillus terranovensis from other Aneurinibacillus species

Species: 1, A. terranovensis (6 strains); 2, A. aneurinilyticus; 3, A. migulanus; 4, A. thermoaerophilus.,$+>85 \%$ positive; (+), $75-84 \%$ positive; v, variable (16-74\% positive); -, 0-15\% positive; $\mathrm{w}$, weak positive reaction; NG, no growth.

\begin{tabular}{|c|c|c|c|c|}
\hline Character & $1^{\star}$ & 2 & 3 & 4 \\
\hline \multicolumn{5}{|l|}{ Growth temperature $\left({ }^{\circ} \mathrm{C}\right)$} \\
\hline Range & $20-55$ & $20-50$ & $20-45$ & $35-65$ \\
\hline Optimum & $37-45$ & $35-40$ & $35-40$ & $50-55$ \\
\hline $\mathrm{pH}$ range & $3 \cdot 5-6 \cdot 0$ & $5-9$ & $6-9$ & $6-9$ \\
\hline Optimum pH & $5 \cdot 0-5 \cdot 5$ & $6 \cdot 5-7 \cdot 0$ & $6 \cdot 5-7 \cdot 0$ & $6 \cdot 5-7 \cdot 0$ \\
\hline $\begin{array}{l}\text { Tough, adherent colony } \\
\text { consistency }\end{array}$ & - & - & - & - \\
\hline Nitrate reduction & $(+)$ & + & + & - \\
\hline \multicolumn{5}{|l|}{ Hydrolysis of: } \\
\hline Casein & NG & - & - & + \\
\hline Gelatin & + & - & + & + \\
\hline Starch & $\mathrm{w}$ & + & + & - \\
\hline \multicolumn{5}{|l|}{ Assimilation of: } \\
\hline D-Alanine & - & + & + & + \\
\hline D-Fructose & $(+)$ & - & + & $\mathrm{v}$ \\
\hline Fumarate & $\mathrm{v}^{\dagger}$ & + & + & + \\
\hline D-Gluconate & $(+)$ & $\mathrm{v}$ & - & - \\
\hline Glutamate & $(+)$ & + & + & + \\
\hline DL-Glycerate & $\mathrm{v}$ & - & - & $\mathrm{v}$ \\
\hline Glycerol & $(+)$ & + & + & + \\
\hline DL-Lactate & $(+)$ & + & + & + \\
\hline Lactulose & - & - & - & - \\
\hline Maltose & - & - & - & - \\
\hline D-Mannitol & $\mathrm{v}$ & - & - & $\mathrm{v}$ \\
\hline $\mathrm{N}$-Acetyl-D-glucosamine & $\mathrm{v}$ & - & - & + \\
\hline Phenylacetate & - & + & + & + \\
\hline Quinate & $\mathrm{v} \dagger$ & - & - & + \\
\hline Sucrose & $\mathrm{v}$ & - & - & - \\
\hline D-Trehalose & $\mathrm{v}$ & - & - & - \\
\hline D-Turanose & - & - & - & $\mathrm{v}$ \\
\hline
\end{tabular}

${ }^{\star} A$. terranovensis strains were characterized at $\mathrm{pH} 5 \cdot 5$; other species were tested at $\mathrm{pH} 6 \cdot 5-7 \cdot 0$.

$\dagger$ Type strain gives a positive reaction.

API 20E tests, the two species could be distinguished from each other by the gelatin reaction; a reaction was evident after $48 \mathrm{~h}$ for Brevibacillus levickii, whereas no reaction was observed in A. terranovensis. However, when the charcoal gelatin was aseptically removed from the API 20E tube and introduced into $1 / 2 \mathrm{BFB}$, gelatin was hydrolysed by Brevibacillus levickii within $24 \mathrm{~h}$ and by $A$. terranovensis after $24 \mathrm{~h}$, but within $48 \mathrm{~h}$. Both species may also be separated on the basis of reaction intensities in the API 20E strip, with stronger reactions for arginine dihydrolase, VogesProskauer and nitrate reduction being observed for $A$. terranovensis and for citrate utilization in Brevibacillus

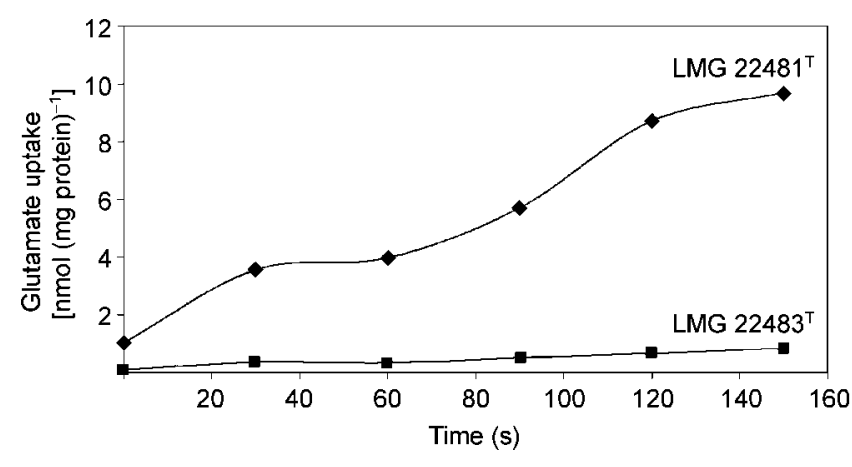

Fig. 5. Uptake of $\left[{ }^{14} \mathrm{C}\right] \mathrm{L}$-glutamic acid in Brevibacillus levickii strain LMG $22481^{\top}$ and Aneurinibacillus terranovensis strain LMG $22483^{\top}$.

levickii. Positive reactions for arginine dihydrolase in the API 20E strip distinguish these species from other members of both genera that have been tested. In the Biotype 100 utilization and acid/alkali production tests, both species demonstrated rapid performance, with substrate utilization (turbidity or acid/alkaline reaction) becoming evident within $24-48 \mathrm{~h}$ incubation. The results produced by the utilization tests were inconsistent within species, especially for the Aneurinibacillus strains; this problem has been seen with other groups of aerobic endospore-formers (Heyrman et al., 2003). The results obtained do, however, indicate that Brevibacillus strains are capable of utilizing a wide range of carbon sources and that the Aneurinibacillus strains utilize a more limited and less consistent range of substrates. The results of the acid/alkali production tests indicated that both species utilize similar kinds of carbon sources, mainly organic acids and amino acids; however, as noted above, these tests were done outside the optimal $\mathrm{pH}$ ranges of these organisms.

\section{Metabolic studies}

Metabolic studies show that both strains utilize glutamate, which is most probably available from cyanobacteria and microalgae in their natural habitats (Siebert \& Hirsch, 1988). Glutamate is non-essential, however, as the organisms grew on a formulation of the defined medium from which it had been omitted. Both species appear to use similar glutamate uptake systems, as experimental outcomes were similar. When grown in the presence of a mixture of amino acids, Brevibacillus levickii strain LMG $22481^{\mathrm{T}}$ demonstrated uptake of $\left[{ }^{14} \mathrm{C}\right] \mathrm{L}$-glutamic acid at a mean rate of $0 \cdot 105 \mathrm{nM} \mathrm{s}^{-1} \mathrm{mg}^{-1}$, whereas A. terranovensis strain LMG $22483^{\mathrm{T}}$ demonstrated uptake at a mean rate of $0.0044 \mathrm{nM} \mathrm{s}^{-1} \mathrm{mg}^{-1}$, over $150 \mathrm{~s}$ (Fig. 5). Perhaps Brevibacillus levickii has a higher affinity uptake system for glutamate on account of nutritional limitations in its habitat. The rate of uptake in the Brevibacillus levickii strain is greater than that of Bacillus sp. strain TA2.A1, which was isolated from a thermal spring and had an L-glutamate uptake of $0.0117 \mathrm{nM} \mathrm{s}^{-1} \mathrm{mg}^{-1}$ in an external glutamate 
concentration of $50 \mu \mathrm{M}$ (Peddie et al., 1999). In comparison, the A. terranovensis strain had a slower rate of uptake than that of Bacillus sp. strain TA2.A1. The uptake system of the Brevibacillus levickii strain appears to be specific for the L-glutamate isomer; this is evident from the fact that D-glutamate caused no inhibition of $\left[{ }^{14} \mathrm{C}\right] \mathrm{L}$-glutamate uptake and that the other amino acids related to Lglutamate (L-proline, L-arginine and DL-ornithine) were fourfold less efficient in inhibiting uptake of $\left[{ }^{14} \mathrm{C}\right] \mathrm{L}$ glutamate than unlabelled L-glutamate, despite being present in excess. This conclusion is supported by the observation that $\left[{ }^{14} \mathrm{C}\right] \mathrm{L}$-proline and $\mathrm{L}$-arginine uptakes were not inhibited by an excess of L-glutamate, which implies that there are separate uptake systems for glutamate, proline and arginine (results not shown). The uptake system of the A. terranovensis strain appeared not to be specific for the L-glutamate isomer, but could transport most of the other related amino acids; the exceptions were L-proline, which caused partial inhibition, and D-glutamate, which caused no inhibition when present in excess (Supplementary Table B in IJSEM Online). No inhibition of $\left[{ }^{14} \mathrm{C}\right] \mathrm{L}$-proline or $\left[{ }^{14} \mathrm{C}\right] \mathrm{L}-$ arginine uptake was observed in $A$. terranovensis pre-grown with L-glutamic acid when in the presence of an excess of unlabelled L-glutamic acid, thus implying that separate uptake systems for proline and arginine exist (results not shown). In Brevibacillus levickii, the ionophores nigericin and valinomycin decreased $\left[{ }^{14} \mathrm{C}\right] \mathrm{L}$-glutamic acid uptake two- and tenfold, respectively. The addition of monensin, however, did not cause any decrease in the rate of uptake (Supplementary Fig. Aa in IJSEM Online). In A. terranovensis, the addition of nigericin resulted in a 40 -fold decrease in the rate of $\left[{ }^{14} \mathrm{C}\right] \mathrm{L}$-glutamic acid uptake and valinomycin caused complete inhibition. Very little inhibition (less than twofold) was observed in the presence of monensin (Supplementary Fig. Ab). Glutamate uptake inhibition by the ionophores valinomycin and nigericin implies that a $\mathrm{K}^{+}$ gradient is involved. However, slight inhibition by monensin in the A. terranovensis strain suggests that a charge gradient may also be involved in the uptake of glutamate in this species. In both strains, the rate of $\left[{ }^{14} \mathrm{C}\right] \mathrm{L}$-glutamic acid uptake in pre-grown cells decreased twofold in the presence of $\mathrm{NaCl}$ at $50 \mathrm{mM}$. In the presence of $\mathrm{KCl}$ at $50 \mathrm{mM}$, the rate of uptake in Brevibacillus levickii decreased fourfold and in A. terranovensis decreased eightfold. In the presence of $\mathrm{HCl}$ at $50 \mathrm{mM}$, cell death occurred in both strains (results not shown). The creation of an artificial $\mathrm{K}^{+}$ gradient resulted in a decrease in the rate of glutamate uptake in both species, thus suggesting that the uptake mechanism is a $\mathrm{K}^{+}$antiport system, with the increased $\mathrm{K}^{+}$ concentration outside the cell inhibiting $\mathrm{K}^{+}$export from inside the cell, hence resulting in decreased glutamate uptake. This is of particular interest given that previous studies on glutamate uptake metabolism in other thermophilic bacteria have shown it to be driven by $\mathrm{Na}^{+}$gradients; Geobacillus stearothermophilus, for example, utilizes a sodium/proton symport mechanism (de Vrij et al., 1990). In the presence of $50 \mathrm{mM}$ sucrose, pre-grown cells of both strains showed no decrease in the rate of $\left[{ }^{14} \mathrm{C}\right] \mathrm{L}$-glutamic acid uptake (data not shown). This lack of inhibition by sucrose demonstrates that the uptake of glutamate in both species is not osmotically sensitive. For both strains, high levels of inhibition of $\left[{ }^{14} \mathrm{C}\right] \mathrm{L}$-glutamic acid uptake occurred through the addition of the energy inhibitors dinitrophenol, iodoacetic acid, $N$-ethylmaleimide $p$-chloromercuribenzoate, carbonyl cyanide $m$-chlorophenyl hydrazone and $\mathrm{N}-\mathrm{N}$ dicyclohexylcarbodiimide (Supplementary Table C in IJSEM Online). Inhibition of $\left[{ }^{14} \mathrm{C}\right] \mathrm{L}$-glutamate uptake by energy inhibitors implies the presence of an active transport system for glutamate. Almost complete inhibition of glutamate uptake in both species by $\mathrm{N}$-N-dicyclohexylcarbodiimide, an inhibitor of ATP synthesis, and iodoacetic acid, a glycolysis inhibitor, suggests a role for ATP in uptake. However, $\mathrm{NaAsO}_{4}$ and $\mathrm{NaF}$, both of which directly inhibit ATP generation, cause only $10 \%$ inhibition of uptake in Brevibacillus levickii strain LMG $22481^{\mathrm{T}}$, thus suggesting that the system does not require ATP directly. This would imply that the mechanism of uptake is not a primary uptake system (directly coupled to ATP hydrolysis), but more likely a secondary transport system that utilizes a gradient. A similar system is probably utilized by A. terranovensis. However, a significant level of inhibition is apparent in the presence of sodium arsenate (Supplementary Table C). Many bacteria can utilize ATP to generate a transmembrane proton-motive force, directly by respiration, which can be coupled to solute uptake. A role for such a proton-motive force in the Brevibacillus and Aneurinibacillus strains is also implied by the inhibition of glutamate uptake by the ionophores. Collectively, the metabolic data indicate that the mechanism of glutamate uptake in Brevibacillus levickii is an energy-dependent, glutamate-specific $\mathrm{K}^{+}$antiport system, whereas in $A$. terranovensis it is an energy-dependent $\mathrm{K}^{+}$antiport system capable of transporting glutamate and other related amino acids.

Perhaps the most interesting feature of these two novel species is that they were not found in the same habitat despite repeated soil sampling on separate occasions, and repeated enrichment and isolation at different times in the laboratory. Brevibacillus levickii strains were only isolated from the north-west slope of Mt Melbourne, whereas A. terranovensis strains were not isolated from this site, but were found in soils from Cryptogam Ridge of Mt Melbourne and in soils from Mt Rittmann. This is reminiscent of the failure of Logan et al. (2000) to isolate Bacillus fumarioli from the north-west slope of Mt Melbourne, although it could be cultivated from Cryptogam Ridge and Mt Rittmann. Although the soil and environmental conditions at each isolation site are superficially similar, our findings clearly imply that there are some important differences between the soil of the north-west slope of Mt Melbourne and those of other sites. Bargagli et al. (1996) found that although mean element concentrations from the fumarolic areas of the two mountains were broadly similar, there were some differences in trace element contents. Soils from Mt Melbourne had higher $\mathrm{Cu}$ and $\mathrm{Zn}$ contents, whereas soils from Mt Rittmann had higher $\mathrm{Cd}$ and $\mathrm{Pb}$; no data for 
the north-west slope of Mt Melbourne have yet been reported. A notable feature of the north-west slope of Mt Melbourne is the near-absence of moss (Broady et al., 1987); this may indicate that this soil contains substances inhibitory to the mosses that otherwise grow so abundantly on the nearby Cryptogam Ridge, or else the soil lacks one or more essential nutrients. Such conditions may also affect the aerobic endospore-forming floras in these soils, and the paucity of moss growth on the north-west slope may limit the organic substrates available to heterotrophic bacteria.

Our failure to identify our Antarctic strains by the genotypic and phenotypic methods applied and the similarities of the members of each group of strains to each other in these analyses support the proposal of two novel species; their descriptions are given below.

\section{Description of Brevibacillus levickii sp. nov.}

Brevibacillus levickii (le.vic.ki'i. N.L. adj. levickii of Levick, named after G. Murray Levick, surgeon and biological scientist of Captain R. F. Scott's Northern Party, the first scientific expedition to visit the vicinity of Mt Melbourne in 1912).

Cells are Gram-positive, becoming Gram-negative after $48 \mathrm{~h}$, motile, round-ended rods $(0 \cdot 7-0 \cdot 8 \times 2 \cdot 0-5 \cdot 0 \mu \mathrm{m})$ occurring singly, in pairs and in chains. Endospores are ellipsoidal, occurring subterminally or terminally in swollen or slightly swollen sporangia (Fig. 4a). After $48 \mathrm{~h}$ incubation at $40^{\circ} \mathrm{C}$ on $1 / 2 \mathrm{BFA}(\mathrm{pH} 5 \cdot 5)$, colonies are circular, flat, up to $3.0 \mathrm{~mm}$ in diameter and cream-coloured with a matt appearance. Colony consistency becomes tough and difficult to break with a loop. Minimum growth temperature lies between 15 and $20^{\circ} \mathrm{C}$, with optimum growth temperature of $40-45^{\circ} \mathrm{C}$ and maximum growth temperature of $50-55^{\circ} \mathrm{C}$. Growth occurs between $\mathrm{pH} 4.5$ and 6.5 and the optimum $\mathrm{pH}$ for growth is $\mathrm{pH} 5 \cdot 0-5 \cdot 5$. Growth is inhibited by $2-3 \% \mathrm{NaCl}$. The organisms are microaerophilic and weakly catalase-positive. Horse blood agar is partially haemolysed. Gelatin is hydrolysed in $24 \mathrm{~h}$ and starch hydrolysis is weakly positive. Casein hydrolysis is weakly positive or negative. In the API 20E strip reactions, arginine dihydrolase, citrate utilization and the VogesProskauer reaction are positive. Gelatin is hydrolysed and nitrate reduction is variable. Reactions for ONPG hydrolysis, lysine decarboxylase, ornithine decarboxylase, hydrogen sulfide production, urease, tryptophan deaminase and indole production are negative. The following carbon sources are utilized in the API Biotype 100 system: $\alpha$-Dglucose, adonitol, aesculin, $\alpha$-lactose, D-alanine, L-alanine, $\mathrm{L}$-arabitol, L-aspartate, $\beta$-D-fructose, cis-aconitate, citrate, fumarate, D-galacturonate, D-gluconate, D-glucuronate, L-glutamate, DL-glycerate, glycerol, 2-keto-D-gluconate, 5-keto-D-gluconate, DL-lactate, D-malate, L-malate, maltose, maltotriose, D-mannitol, D-mannose, meso-tartrate, 1 - $O$-methyl- $\beta$-galactopyranoside, $\quad 1$ - $O$-methyl- $\beta$-D-glucopyranoside, $\mathrm{N}$-acetyl-D-glucosamine, L-proline, putrescine, quinate, L-serine, D-sorbitol, succinate, sucrose and trans-aconitate. Utilization of the following substrates is variable: DL- $\alpha$-amino-n-butyrate, 2 -oxoglutarate, D-galactose, $\beta$-gentobiose, mucate, $\mathrm{D}$-ribose, $\mathrm{D}$-saccharate, $\mathrm{D}$-trehalose and L-tryptophan. The following carbon sources are not utilized: i-erythritol, DL- $\alpha$-amino-n-valerate, $\alpha$-D-melibiose, L-arabinose, D-arabitol, benzoate, betaine, DL- $\beta$-hydroxybutyrate, caprate, caprylate, D-cellobiose, dulcitol, ethanolamine, $\alpha$-L-fucose, gentisate, D-glucosamine, glutarate, histamine, L-histidine, hydroxyquinoline- $\beta$-glucuronide, itaconate, lactulose, D-lyxose, malonate, maltitol, $m$ coumarate, D-melezitose, 1-O-methyl- $\alpha$-D-glucopyranoside, 3-O-methyl-D-glucopyranose, 1-O-methyl- $\alpha$-galactopyranoside, $m$-hydroxybenzoate, myo-inositol, palatinose, phenylacetate, 3-phenylpropionate, p-hydroxybenzoate, propionate, protocatechuate, D-raffinose, $\alpha$-L-rhamnose, L-sorbose, D-tagatose, D-tartrate, L-tartrate, tricarballyate, trigonelline, tryptamine, D-turanose, L-tyrosine, xylitol and D-xylose. The following substrates in API Biotype 100 produce alkaline reactions when inoculated with a suspension in $1 / 2 \mathrm{BFB}$ prepared without yeast extract or $\left(\mathrm{NH}_{4}\right)_{2} \mathrm{SO}_{4}$, but containing $0.006 \%$ phenol red: 2-oxoglutarate, L-aspartate, fumarate, D-galacturonate, D-gluconate, L-glutamate, D-malate, L-malate, malonate, mucate, quinate, D-saccharate, succinate, D-tartrate, L-tartrate and tricarballyate. Alkaline reactions for the following substrates are variable: 2-keto-D-gluconate, L-alanine, caprylate, cis-aconitate, citrate, D-glucuronate, glutarate, DL-glycerate, L-histidine, itaconate, DL-lactate, meso-tartrate, propionate, L-serine, trans-aconitate and L-tryptophan.

The major cellular fatty acid is anteiso- $\mathrm{C}_{15: 0}$, accounting for approximately $74 \%$ total fatty acid content. The following fatty acids are present in smaller amounts (at least $1 \%$ ): iso- $C_{14: 0}$, iso- $C_{15: 0}, C_{16: 0}$, iso- $C_{16: 0}$, summed feature 4 (iso- $\mathrm{C}_{17: 1}$ and/or anteiso- $\mathrm{C}_{17: 1}$ ) and anteiso- $\mathrm{C}_{17: 0}$ (detailed fatty acid data are given in Supplementary Table A).

The DNA G $+\mathrm{C}$ content is $48 \cdot 3-50 \cdot 3 \mathrm{~mol} \%$ and the $\mathrm{G}+\mathrm{C}$ content of the type strain $\left(\operatorname{Logan} \mathrm{B}-1657^{\mathrm{T}}=\mathrm{LMG} 22481^{\mathrm{T}}=\right.$ CIP $108307^{\mathrm{T}}$ ) is $50 \cdot 3 \mathrm{~mol} \%$. In the variable reactions listed above, the type strain is weakly positive for casein hydrolysis and it utilizes DL- $\alpha$-amino-n-butyrate, 2-oxoglutarate, Dgalactose, D-ribose, D-trehalose and L-tryptophan; alkaline reactions are observed for D-glucuronate, itaconate, 2-ketoD-gluconate, meso-tartrate and L-tryptophan.

\section{Description of Aneurinibacillus terranovensis sp. nov.}

Aneurinibacillus terranovensis [terr.a.no.ven'sis. N.L. adj. terranovensis referring to Terra Nova Bay Station (Italy), northern Victoria Land, Antarctica, where the strains were first isolated].

Cells are Gram-positive, becoming Gram-negative after $48 \mathrm{~h}$, motile, round-ended rods $(0 \cdot 8-1 \cdot 0 \times 2 \cdot 0-8 \cdot 0 \mu \mathrm{m})$, occurring singly, in pairs and in chains. Endospores are ellipsoidal, occurring paracentrally and subterminally in 
very swollen sporangia (Fig. $4 \mathrm{~b}$ ). After $48 \mathrm{~h}$ incubation on $1 / 2 \mathrm{BFA}(\mathrm{pH} 5 \cdot 5)$ at $40^{\circ} \mathrm{C}$, colonies are circular, flat, up to $1.5 \mathrm{~mm}$ in diameter and cream-coloured with a slightly glossy appearance and butyrous consistency. Minimum growth temperature is $20-25^{\circ} \mathrm{C}$, with optimum growth at $37-45^{\circ} \mathrm{C}$ and maximum growth temperature of $50-55^{\circ} \mathrm{C}$. Growth occurs between pH 3.5 and 6.0 and the optimum $\mathrm{pH}$ for growth is $\mathrm{pH} 5 \cdot 0-5 \cdot 5$. Growth is inhibited by $2-$ $3 \% \mathrm{NaCl}$. Microaerophilic and weakly catalase-positive. Gelatin is hydrolysed after $48 \mathrm{~h}$. Starch is weakly hydrolysed. No growth occurs on casein agar. In the API 20E strip reactions, arginine dihydrolase, the Voges-Proskauer reaction and nitrate reduction are positive. Citrate utilization is variable. Reactions for ONPG hydrolysis, lysine decarboxylase, ornithine decarboxylase, hydrogen sulfide production, urease, tryptophan deaminase, indole production and gelatin hydrolysis are negative. The following carbon sources are utilized in the Biotype 100 system: aesculin, $\beta$-D-fructose, D-gluconate, $\alpha$-D-glucose, L-glutamate, glycerol, DL-lactate, D-mannose, 1 -O-methyl- $\beta$-Dglucopyranoside and myo-inositol. Utilization of the following substrates is variable: adonitol, 2-oxoglutarate, $\alpha$-lactose, L-alanine, D-arabitol, L-arabitol, L-aspartate, DL- $\beta$-hydroxybutyrate, cis-aconitate, citrate, fumarate, Dgalactose, D-galacturonate, D-glucosamine, DL-glycerate, 2keto-D-gluconate, 5-keto-D-gluconate, D-malate, L-malate, D-mannitol, meso-tartrate, 1 - $O$-methyl- $\beta$-galactopyranoside, $\mathrm{N}$-acetyl-D-glucosamine, L-proline, putrescine, quinate, D-ribose, D-sorbitol, succinate, sucrose, trans-aconitate and D-trehalose. The following carbon sources are not utilized: 3-phenylpropionate, DL- $\alpha$-amino-n-butyrate, DL$\alpha$-amino-n-valerate, $\alpha$-D-melibiose, D-alanine, $\alpha$-L-fucose, $\alpha$-L-rhamnose, L-arabinose, benzoate, betaine, $\beta$-gentobiose, caprate, caprylate, D-cellobiose, dulcitol, ethanolamine, gentisate, D-glucuronate, glutarate, histamine, L-histidine, hydroxyquinoline- $\beta$-glucuronide, i-erythritol, itaconate, lactulose, D-lyxose, malonate, maltitol, maltose, maltotriose, $m$-coumarate, D-melezitose, 1-O-methyl- $\alpha$-D-glucopyranoside, 1-O-methyl- $\alpha$-galactopyranoside, 3-O-methyl-D-glucopyranose, $m$-hydroxybenzoate, mucate, phenylacetate, p-hydroxybenzoate, palatinose, propionate, protocatechuate, D-raffinose, D-saccharate, L-serine, L-sorbose, Dtagatose, D-tartrate, L-tartrate, tricarballyate, trigonelline, tryptamine, L-tryptophan, D-turanose, L-tyrosine, xylitol and D-xylose. The following substrates in API Biotype 100 produce alkaline reactions when inoculated with a suspension in $1 / 2 \mathrm{BFB}$ prepared without yeast extract or $\left(\mathrm{NH}_{4}\right)_{2} \mathrm{SO}_{4}$, but containing $0.006 \%$ phenol red: 2oxoglutarate, L-aspartate, cis-aconitate, citrate, fumarate, D-galacturonate, D-gluconate, L-glutamate, glutarate, DLglycerate, malonate, mucate, quinate, D-saccharate, succinate, L-tartrate and D-tartrate. Alkaline reactions for the following substrates are variable: D-alanine, L-alanine, DL- $\beta$ hydroxybutyrate, caprylate, D-glucuronate, L-histidine, DL-lactate, D-malate, L-malate, meso-tartrate, L-proline, propionate, L-serine, trans-aconitate, tricarballyate and L-tryptophan.
The major cellular fatty acids are anteiso- $\mathrm{C}_{15: 0}$ and iso$\mathrm{C}_{15 \text { : } 0}$, accounting for approximately 41 and $46 \%$ total fatty acid content, respectively. The following fatty acids are present in smaller amounts (at least 1.0\%): $\mathrm{C}_{14: 0}$, iso- $\mathrm{C}_{14: 0}$, $\mathrm{C}_{16: 0}$, iso- $\mathrm{C}_{16: 0}$ and $\mathrm{C}_{16: 1} \omega 7 \mathrm{c}$ alcohol (detailed fatty acid are given in Supplementary Table A).

The G $+\mathrm{C}$ content is $43 \cdot 2-44 \cdot 6 \mathrm{~mol} \%$ and the $\mathrm{G}+\mathrm{C}$ content of the type strain $\left(\operatorname{Logan} \mathrm{B}-1599^{\mathrm{T}}=\mathrm{LMG} 22483^{\mathrm{T}}=\mathrm{CIP}\right.$ $108308^{\mathrm{T}}$ ) is $43.2 \mathrm{~mol} \%$. In the variable reactions listed above, the type strain utilizes citrate, fumarate, D-galactose, D-glucosamine, $\alpha$-lactose, L-malate, quinate and transaconitate; alkaline reactions are observed in DL-lactate, D-malate, L-malate and trans-aconitate.

\section{ACKNOWLEDGEMENTS}

N. A. L is exceptionally grateful to PNRA for the invitation to join the 14th Italian Antarctic Expedition (1998-1999), to Dr D. W. H. Walton and the British Antarctic Survey for enabling him to join that expedition, and to the Trans-Antarctic Association (Cambridge; grant no. TAA/98/16) and the Worshipful Company of Scientific Instrument Makers (London) for financial support. We are very grateful to N. J. Russell and D. D. Wynn-Williams for collecting soil samples from Mt Rittmann and Mt Melbourne during the 1995-1996 season. The visit to Cryptogam Ridge, Mt Melbourne, a Specially Protected Area, was covered by permit no. S12\&13/2/98 from the Foreign and Commonwealth Office, London. We thank H. G. Trüper for advice on nomenclatural etymology. We thank Abdul Hadi Ali Albaser for details of the phenol red indicator medium for the API Biotype 100 system and Daniel Smith for salt tolerance data. R. N. A. thanks Glasgow Caledonian University for research studentship funding and Louise Mullen for performing primary metabolic work. We are most grateful to bioMérieux for providing API materials. P.D. V. is indebted to the National Fund for Scientific Research, Flanders (FWO, Vlaanderen) for personnel and research grant G.0156.02. J.H. is most grateful to the BOF (UGent) for a personal grant.

\section{REFERENCES}

Armienti, P. \& Tripodo, A. (1991). Petrography and chemistry of lavas and comagmatic xenoliths of Mt Rittmann, a volcano discovered during the IV Italian expedition in northern Victoria Land (Antarctica). Mem Soc Geol It 46, 427-451.

Bargagli, R., Broady, P. A. \& Walton, D. W. H. (1996). Preliminary investigation of the thermal biosystem of Mount Rittmann fumaroles (northern Victoria Land, Antarctica). Antarct Sci 8, 121-126.

Bonaccorso, A., Maione, M., Pertusati, P. C., Privitera, E. \& Ricci, C. A. (1991). Fumarolic activity at Mt Rittmann volcano (northern Victoria Land, Antarctica). Mem Soc Geol It 46, 453-456.

Broady, P. A. (1993). Soils heated by volcanism. In Antarctic Microbiology, pp. 413-432. Edited by E. I. Friedmann. New York: Wiley-Liss.

Broady, P. A., Given, D. R., Greenfield, L. G. \& Thompson, K. (1987). The biota and environment of fumaroles on Mt Melbourne, northern Victoria Land. Polar Biol 7, 97-113.

Cruickshank, R., Duguid, J. P., Marmion, B. P. \& Swain, R. H. A. (1975). Medical Microbiology, vol. 2, pp. 109. Edinburgh: Churchill Livingstone. 
de Vrij, W., Speelmans, G., Heyne, R. I. R. \& Konings, W. N. (1990). Energy transduction and amino acid transport in thermophilic aerobic and fermentative bacteria. FEMS Microbiol Rev 75, 183-200.

Dijkhuizen, L., Arfman, N., Attwood, M. M., Brooke, A. G., Harder, W. \& Watling, E. M. (1988). Isolation and initial characterization of thermotolerant methylotrophic Bacillus strains. FEMS Microbiol Lett 52, 209-214.

Duguid, J. (1951). The demonstration of bacterial capsules and slime. J Pathol Bacteriol 63, 673.

Ezaki, T., Hashimoto, Y. \& Yabuuchi, E. (1989). Fluorometric deoxyribonucleic acid-deoxyribonucleic acid hybridization in microdilution wells as an alternative to membrane filter hybridization in which radioisotopes are used to determine genetic relatedness among bacterial strains. Int J Syst Bacteriol 39, 224-229.

Gordon, R. E., Haynes, W. C. \& Pang, C. H.-N. (1973). Genus Bacillus. Agriculture Handbook no. 427. Washington, DC: United States Department of Agriculture.

Goto, K., Fujita, R., Kato, Y., Asahara, M. \& Yokota, A. (2004). Reclassification of Brevibacillus brevis strains NCIMB 13288 and DSM 6472 (=NRRL NRS-887) as Aneurinibacillus danicus sp. nov. and Brevibacillus limnophilus sp. nov. Int J Syst Evol Microbiol 54, 419-427.

Heyrman, J., Balcaen, A., Rodriguez-Diaz, M., Logan, N. A., Swings, J. \& De Vos, P. (2003). Bacillus decolorationis sp. nov., isolated from biodeteriorated parts of the mural paintings at the Servilia tomb (Roman necropolis of Carmona, Spain) and the SaintCatherine chapel (Castle Herberstein, Austria). Int J Syst Evol Microbiol 53, 459-463.

Logan, N. A. \& Berkeley, R. C. W. (1984). Identification of Bacillus strains using the API system. J Gen Microbiol 130, 1871-1882.

Logan, N. A., Lebbe, L., Hoste, B. \& 7 other authors (2000). Aerobic endospore-forming bacteria from geothermal environments in northern Victoria Land, Antarctica, and Candlemas Island, South Sandwich archipelago, with the proposal of Bacillus fumarioli sp. nov. Int J Syst Evol Microbiol 50, 1741-1753.

Logan, N. A., Forsyth, G., Lebbe, L. \& 8 other authors (2002). Polyphasic identification of Bacillus and Brevibacillus strains from clinical, dairy and industrial specimens and proposal of Brevibacillus invocatus sp. nov. Int J Syst Evol Microbiol 52, 953-966.
Nicolaus, B., Marsiglia, F., Esposito, E., Trincone, A., Lama, L., Sharp, R., di Prisco, G. \& Gambacorta, A. (1991). Isolation of five strains of thermophilic eubacteria in Antarctica. Polar Biol 11, 425-429.

Pearson, W. R. \& Lipman, D. J. (1988). Improved tools for biological sequence comparison. Proc Natl Acad Sci U S A 85, 2444-2448.

Peddie, C. J., Cook, G. M. \& Morgan, H. W. (1999). Sodiumdependent glutamate uptake by an alkaliphilic, thermophilic Bacillus strain, TA2.A1. J Bacteriol 181, 3172-3177.

Pot, B., Vandamme, P. \& Kersters, K. (1994). Analysis of electrophoretic whole-organism protein fingerprints. In Modern Microbial Methods (Chemical Methods in Prokaryotic Systematics Series), pp. 493-521. Edited by M. Goodfellow \& A. G. O’Donnell. Chichester: Wiley.

Shida, O., Takagi, H., Kadowaki, K. \& Komagata, K. (1996). Proposal for two new genera, Brevibacillus gen. nov. and Aneurinibacillus gen. nov. Int J Syst Bacteriol 46, 939-946.

Siebert, J. \& Hirsch, P. (1988). Characterization of 15 selected coccal bacteria isolated from Antarctic rock and soil samples from the McMurdo-Dry Valleys (South-Victoria Land). Polar Biol 9, 37-44.

Stackebrandt, E. \& Goebel, B. M. (1994). Taxonomic note: a place for DNA-DNA reassociation and $16 \mathrm{~S}$ rRNA sequence analysis in the present species definition in bacteriology. Int J Syst Bacteriol 44, 846-849.

Stackebrandt, E., Frederiksen, W., Garrity, G. M. \& 10 other authors (2002). Report of the ad hoc committee for the re-evaluation of the species definition in bacteriology. Int J Syst Evol Microbiol 52, 1043-1047.

Suzuki, K., Goodfellow, M. \& O’Donnell, A. G. (1993). Cell envelopes and classification. In Handbook of New Bacterial Systematics, pp. 195-250. Edited by M. Goodfellow \& A. G. O’Donnell. London: Academic Press.

Vauterin, L. \& Vauterin, P. (1992). Computer aided objective comparison of electrophoretic patterns for grouping and identification of microorganisms. Eur Microbiol 1, 37-41.

Willems, A., Doignon-Bourcier, F., Goris, J., Coopman, R. de Lajudie, P., De Vos, P. \& Gillis, M. (2001). DNA-DNA hybridization study of Bradyrhizobium strains. Int J Syst Evol Microbiol 51, 1315-1322. 